\title{
THE QUALITY OF CORN SILAGE PRODUCT FROM TECHNOPARK OF BANYUMULEK LOMBOK, WEST NUSA TENGGARA
}

\section{KUALITAS PRODUK SILASE JAGUNG DARI TEKNOPARK BANYUMULEK LOMBOK, NUSA TENGGARA BARAT}

\author{
Nurul Fitri Sari*, Roni Ridwan, and Yantyati Widyastuti \\ Research Center for Biotechnology, Indonesian Institute of Sciences, Cibinong 16911
}

Submitted: 25 October 2016, Accepted: 2 March 2017

\section{INTISARI}

Provinsi Nusa Tenggara Barat merupakan salah satu provinsi yang berpotensi dalam peternakan sapi pedaging dan terpilih sebagai lokasi untuk pengembangan Teknopark di Banyumulek. Pengawetan hijauan makanan ternak berupa silase merupakan program untuk mendukung ketersediaan hijauan makanan ternak untuk sapi pedaging. Silase dibuat dari tanaman jagung dengan penambahan dedak dan Lactobacillus plantarum 1A-2 sebagai inokulum. Tiga percobaan dilakukan dengan 10 pengulangan pada tiap bulannya dan dilakukan dengan rancangan acak kelompok. Kualitas silase dievaluasi berdasarkan analisis kimia dan mikrobiologi, hasil analisis menunjukkan bahwa produk silase yang dibuat pada waktu 3 bulan di Teknopark Banyumulek memiliki kualitas yang baik dan stabil.

(Kata kunci: Kestabilan, Lactobacillus plantarum 1A-2, qPCR, Silase, Tanaman jagung, Teknopark Banyumulek)

\begin{abstract}
West Nusa Tenggara province is one potential area for farming of cattle and has been chosen as location for developing a Technopark in Banyumulek. Forage preservation as silage is a program to support the sustainability of forage for beef cattle. Silage was made using whole corn crop and additives of rice bran and Lactobacillus plantarum 1A-2 as inoculum under a block randomized design. Three treatments were given and 10 replications of each month. Evaluation of silage quality, based on chemical and microbiological analysis, showed that silage making during 3 months in Technopark Banyumulek is good and stable.
\end{abstract}

(Key words: Lactobacillus plantarum 1A-2, Silage, Stability, Technopark of Banyumulek, Whole corn crop)

\section{Introduction}

West Nusa Tenggara province has a history as a producer of livestock, especially beef cattle. The province has fertile condition so that farming is potential. The province has also launched a program called 'Bumi Sejuta Sapi' (NTB-BSS) in 2012, which targeted there are one million of cattle in the province. Related to the government's program on developing of some Technoparks, West Lombok was appointed site for developing a Technopark supervised by the Indonesian Institutes of Sciences (LIPI). The plan for developing an 'Integrated Farming System of Technopark Banyumulek based on the utilization of sustainable bioresources' program in the district of Banyumulek, is very appropriate due to its long history of agriculture practices. Livestock is one of the main economic activities of the community which is expected to support the government program of national food sovereignty. Livestock is instrument to provide sufficient animal protein needed by society. Generally in Indonesia, livestock are controlled by smallscale farmers that often constrained by their simple technology back ground. Efforts to improve the knowledge of farmers can be done through technology transfer by training.

\footnotetext{
* Korespondensi (corresponding author):

Telp. +62 218754587

E-mail: nurulfitrisari@gmail.com
} 
Forages are the main component of feed for ruminants regarding to the anatomy of their digestive tract as herbivore animal. Therefore, forage should always be available in sufficient quantity and quality to maintain the productivity of ruminants. However, the availability of forage is often hampered by climatic conditions, especially drought. The way to overcome this problem is to preserve forage into silage, which can be used as a substitute for fresh forage. Ensiling is forage preservation process under anaerobic fermentation condition (McDonald et al., 1991). Ensiling reduce $\mathrm{pH}$ of forage raw material through homofermentative process of major water soluble carbohydrate (WSC) that carried out by lactic acid bacteria (LAB) to convert soluble carbohydrates into lactic acid, thereby harmful microorganism can be inhibited and nutrient content can be preserved (Sun et al., 2009).

The $L A B$ are naturally present in the plant as epiphyte so it can automatically play a role at the time of fermentation, but to optimize the phase ensilage it is recommended to add an additive such as inoculum of $L A B$ and other additives to assure a perfect lactic acid fermentation (Bolsen et al., 1995). Even lactic acid bacteria as inoculum of silage can also have an opportunity as probiotic because it is still able to survive and reach the main part of the ruminant stomach i.e. the rumen (Weinberg et al., 2004).

Production of silage needs strongly availability of enough quantity of forage maintained by intensive cultivation and appropriate technology. Therefore the technology transfer efforts in silage making is needed. Related to this, LIPI as a research institution has been transferred silage making technology to the community, especially under coordination with Balai Pengolahan dan Pengembangan Pakan Ternak Ruminansia (BP3TR) in Banyumulek. It is expected that silage products that manufactured in BP3TR has a good quality through long experience in silage making based on technology transferred to the community. Technology of fermented forage as silage has been developed in our laboratory and has been disseminated to many farmer groups in many provinces in Indonesia.

Corn and sorghum are the most appropriate grasses to make silages due to their high soluble carbohydrate contents and dry matter production. However, some studies have shown that different grasses can be utilized if they are ensilage at the right developmental stage or if appropriate additives are used (Zanine et al., 2010). Corn crop is a high-quality forage that is used by many farms. Its popularity is due to the high yield of a very digestible, high-energy crop, and the ease of adapting it to mechanized harvesting and feeding. Corn crop is ideal material and fits the requirement for silage making. Preserving corn crop is needed in order to ensure this crop is available all year around. The objective of this study was to evaluate the stability of silage quality and validate corn silage produced in the Technopark Banyumulek.

\section{Materials and Methods}

\section{Materials}

The whole-crop corn was collected from the Agrostology Field of BP3TR in Banyumulek, Lombok and harvested at 90 days after planting. Rice bran was from local market in Lombok. Inoculant of Lactobacillus plantarum 1A-2 was from the Research Center for Biotechnology-LIPI.

\section{Methods}

Ensiling. The whole-crop corn were harvested at about 5 p.m. and air-dried overnight for wilting. The whole-crop corn were chopped to length of approximately 5 $\mathrm{cm}$. The chopped whole-crop corn were added $5 \%$ of rice bran as carbohydrate source and mixed with inoculum of $L$. plantarum $1 \mathrm{~A}-2$ of $2.5 \times 10^{6} \mathrm{cfu} / \mathrm{g}$ silage materials population density approximately. All silages were prepared using plastic drum silos (about 80 $\mathrm{kg}$ ) and then incubated at room temperature for 30 days. Silage making was based on different months

Silage preparation and analysis. After 30 days, silos were opened, silage was harvested and samples of silage were then transported to laboratory in Research Center for Biotechnology LIPI Cibinong for analysis. There were 30 samples during three months. Sample of silage was divided into 2 parts. One part was oven-dried at $60^{\circ} \mathrm{C}$ and milled to pass through a 0.5 to $1 \mathrm{~mm}$ aperture sieve for proximate analysis. The second part was for silage juice for detecting the $\mathrm{pH}$ and lactic acid bacteria population; while the rest was stored at $-20^{\circ} \mathrm{C}$ for the bacterial quantification measurement by extracting silage juice. Silage juice was made using a blender, with the addition of sterilized distilled water to the 
silage samples $(1: 1 \mathrm{w} / \mathrm{v})$; the juice was then filtered using sterilized double cheese clothes and then placed into a $15 \mathrm{~mL}$ sterilized corning tube.

Silage quality evaluation. Measurement of silage DM was not possible to be carried out in Banyumulek due to lack of oven, meanwhile transportation of silage samples took place about 2 days, so that it was difficult to obtain fresh silage.

Silage samples were analyzed using the proximate standard procedures of AOAC (2005) and followed the manufacturer's procedure of FOSS instrument (Hoganas, Sweden. Dry matter (DM) analysis was analyzed using oven (Thermo scientific). Crude protein (CP) was analyzed using Kjeltec $^{\text {TM }} 8400$ (FOSS). Crude fiber (CF) was analyzed using Fibertec ${ }^{\mathrm{TM}} 2010$ (FOSS). Other parameters were also tested, including pH using Cyberscan pH310 Eutech, lactic acid bacteria population was determined by total plate count (TPC) using MRS agar (Cappucino and Sherman, 2001). Microbial quantification analysis using real-time PCR Qiagen (Klocke et al., 2006).

DNA extraction from silage samples. The DNAs of silage juice were extracted by using Genomic DNA Mini Kit based on Buffy Coat Protocol (Geneaid) (Ridwan et al., 2015). Extraction of DNAs was modified such as addition of Proteinase $\mathrm{K}$ (final concentration of $2 \mathrm{mg} / \mathrm{mL}$ ), Lisozyme (final concentration of $25 \mathrm{mg} / \mathrm{mL}$ ) and RNAse A (final concentration of $10 \mathrm{mg} / \mathrm{mL}$ ), and then incubated at $60^{\circ} \mathrm{C}$ for $30 \mathrm{~min}$. DNAs product of total lactic acid bacteria were used for quantification of $L$. plantarum by qPCR method, respectively.

Quantitative Real Time PCR (qPCR). The analysis of qPCR was performed as described by Klocke et al., (2006) by using the Rotorgene Q Qiagen in accordance with the manufacturer's instructions and the dsDNAbinding dye SYBR Greenl with pair specific primers of $L$. plantarum. The total qPCR reaction was determined in a $20 \mu \mathrm{L}$ final volume consisted of $10 \mu \mathrm{L}$ of Quantifast ${ }^{\circledR}$ SYBR $^{\circledR}$ Green PCR Kit, $1 \mu \mathrm{L}$ of each specific primer ( $F \& R), 6 \mu L$ of pure distilled water, and $2 \mu \mathrm{L}$ of extracted DNA sample from each treatment. The copy number of $L$. plantarum in samples was determined by using $L$. plantarum cells as a standard. Data were analyzed by using the Rotor-Gene Q Series Software 1.7.Ink version. The qPCR analysis was used for quantification the real specific population of LAB in the silage.

\section{Statistical analysis}

Silage making was designed by a block randomized based on different months with ten replications of each month. Data were analyzed by using ANOVA with SPSS 16 for windows. Significant effects of each treatment were further analyzed by using the least significant difference by Duncan Test $(P<0.05)$.

\section{Result and Discussion}

Overall, in this study, the quality were good during three months as shown in figure 1. Beside $\mathrm{pH}$, color and texture of silage are variable quality of silage. Silage produced in Technopark Banyumulek met the good quality of silage, either color and texture, which is golden brown and tender and because the quality of silage that produced in Banyumulek was good, the fungi did not found in the silage.

Chemical analysis of silage quality is very important to evaluate the nutrient content of silage. Proximate analysis is one of parameter to determine the quality of silage. The total of silage samples are representative from the silage production. The nutrition composition of corn silage is showed in the Table 1. Silage dry matter analysis in July showed the highest value compared with other months. The reason is that July is the highest peak of drought season (BMKG, 2015) which caused reduction of moisture content of the raw material. The natural environment condition is very important in controlling the rate of moisture loss. McDonald et al. (1991) stated that environment such as weather factor, pressure deficit, wind speed, and rainfall play important role in the moisture loss. For example in between 09.00 - 12.00 a.m., radiation increases to a maximum and a high proportion of this is used for latent heat of evaporation, giving a high swath evaporation rate which includes the evaporation of any external surface water such as dew or rain and internal plant water. The vapour pressure deficit during this phase, increases to maximum values and swath resistance is low, but it is begin to increase slowly. Therefore, during the morning high swath evaporation rate result from the high levels of availability energy and ambient vapour pressure deficit and the low 
resistance of the swath. Indirectly, dry matter content of raw material affected the value of materials dry matter.

Fermentation treatment of silage making during 3 months period showed not significant different in CF content, means that fermentation process during 3 months period in silage making is stable. Similarly, CP showed stable value during 3 months period. Based on the results of CF and CP value of silage samples, it is shown that the technology of silage making have been practiced in good way by the community in Banyumulek. Another parameter to evaluate silage quality is microbiological analysis on LAB population characteristic of silage which is presented in Figure 2.

When whole crop corn is chopped for silage it will generally ensile very efficiently.
The high level of carbohydrates helps to ensure that abundance of lactic acid for preservation will be produced. If condition for chopping or storing the silage are not ideal, fermentation may be delayed, causing a loss of nutrient and bad silage quality. Inoculation of lactic acid bacteria to corn plant prior to ensiling was aimed to provide a good environment for lactic acid bacteria to do fermentation, enhanced the desirable microflora, decreased the growth of spoilage fungi or yeast in order to produce a good quality silage (Amado et al., 2012). Inoculum of lactic acid bacteria was originally used to reduce $\mathrm{pH}$ and to avoid the risk of clostridial fermentation by the native bacterial population (Wilkinson et al., 2003). L. plantarum has the potential to increase the production of lactic acid because it is belong to homofermentative
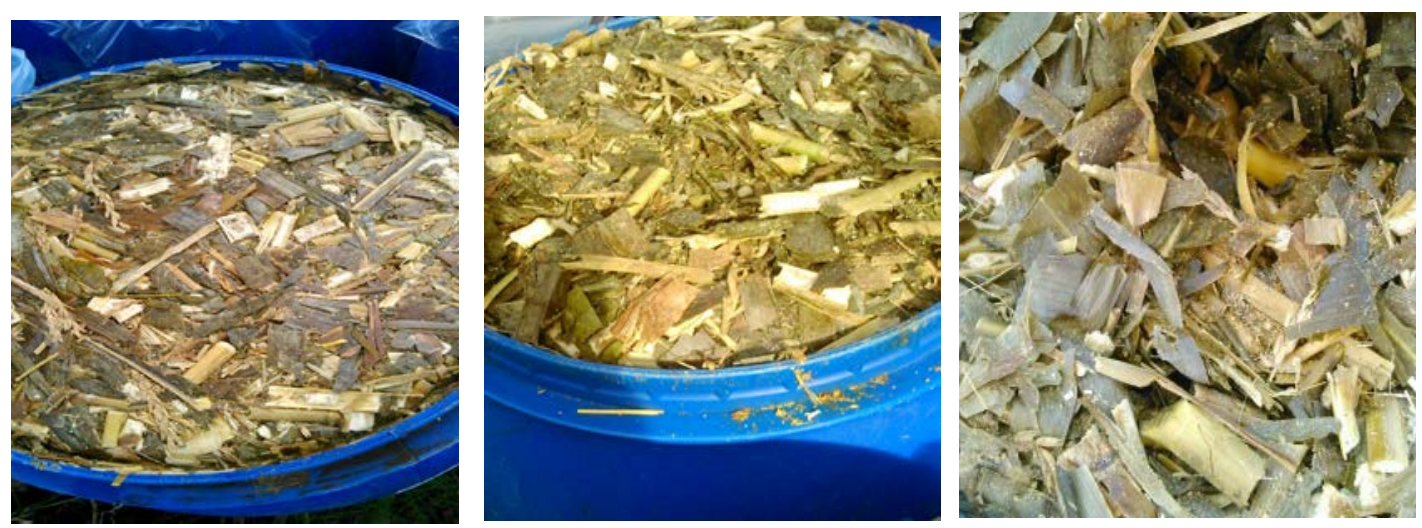

Table 1. Nutrient composition of corn silage

\begin{tabular}{lccc}
\hline \hline \multicolumn{1}{c}{ Period } & Dry matter analysis (\%) & Crude fiber (\%) & Crude protein (\%) \\
\hline July & 92.23 & 30.89 & 8.32 \\
August & 89.31 & 31.90 & 8.35 \\
September & 87.33 & 32.39 & 8.27 \\
P-Value & 0 & 0.99 & 0.431 \\
\hline Note : Means in the same row with different small superscript differ significantly $(\mathrm{P}<0.05)$ &
\end{tabular}

Note : Means in the same row with different small superscript differ significantly $(P<0.05)$

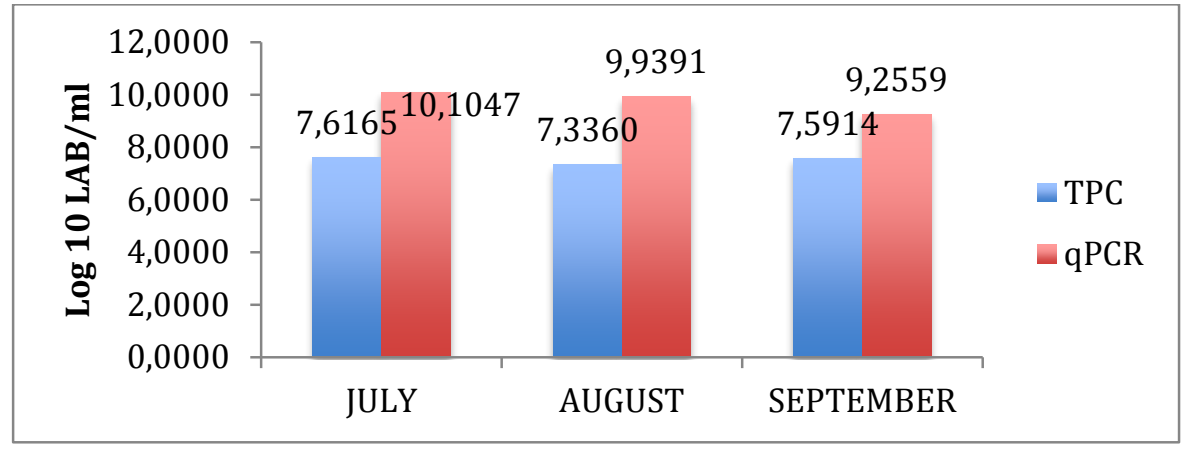

Figure 2. Number of lactic acid bacteria 
group (McDonald et al., 1991; Lynch et al., 2012). This finding suggests that $L$. plantarum population was sufficiently established during ensiling process and able to utilize the high concentration of $\mathrm{NH}_{3}-\mathrm{N}$. The $\mathrm{NH}_{3}-\mathrm{N}$ in the silage was used as a source of $\mathrm{N}$ for microbial protein synthesis, for microbial growth (McDonald et al., 1991; Norton, 1994). During the ensilage process, LAB produced lactic acid to lower the $\mathrm{pH}$ and inhibit the growth of undesirable microorganisms, and produced good quality silage (Ridwan et al., 2015).

Quantitative PCR (qPCR) has been used to quantify several different species of fermentative bacteria in several natural and engineered environments (Coeuret et al., 2004; Grattepanche et al., 2004; Lin et al., 1992; Tajima et al., 2001). The data presented here represent the first report of the use of QPCR to systematically quantify different specific lactic acid bacteria population in conserved forages in the tropics, although Klocke et al. (2006) have recently used qPCR based on 16S rDNA directed primers to quantify $L$. plantarum in grass silage.

In this study, value of total $L A B$ from analysis of TPC and QPCR is different because of real time PCR (qPCR) quantifies both viable and non-viable cells. This technique has the advantage of targeting species and being a very sensitive, accurate and reproducible method that enables underlining of slight changes and allows the differentiation between the population sizes of bacteria (Mosoni et al., 2007). Klocke et al. (2006) reported that the population of lactic acid bacteria using qPCR analysis in silage which is added by mixed additive showed 4.1 $x 10^{11} \mathrm{cfu}^{\prime / t-1}$ silage. Real-Time PCR focuses on the exponential phase because it provides the most precise and accurate data for quantitation. Within the exponential phase, the real-time PCR instrument calculates two values. The threshold line is the level of detection at which a reaction reaches a fluorescent intensity above background. The PCR cycle at which the sample reaches this level is called the Cycle Threshold (Ct). The Ct value is used in downstream quantitation or presence or absence detection. By comparing the $\mathrm{Ct}$ values of samples of unknown concentration with a series of standards, the amount of template DNA in an unknown reaction can be accurately determined. Its sensitivity and accuracy allows the differentiation of slight changes in bacterial numbers that cannot be seen using microbial techniques or other molecular approaches (16S probing and competitive PCR) (Kobayashi et al., 2004).

The $\mathrm{pH}$ of silages produced was below 4.2, means that silages were well fermented. Theses results agreed with Eweedah et al. (2005), who mentioned that the silage with the $\mathrm{pH}$ value of 4,2 or less could be the good silage. The $\mathrm{pH}$ value of silage below 4,4 has been considered as an index of good silage (Harrison et al., 1995) whereas LAB still survive to preserve forages. Based on data in figure 3 , there was correlation between the number of lactic acid bacteria and $\mathrm{pH}$, it was showed that the number of $L A B$ in July and September had the higher value of $L A B$ population than August because the effect of lower $\mathrm{pH}$. The function of $L A B$ inoculants is to accelerate the rapid and effiecient utilization

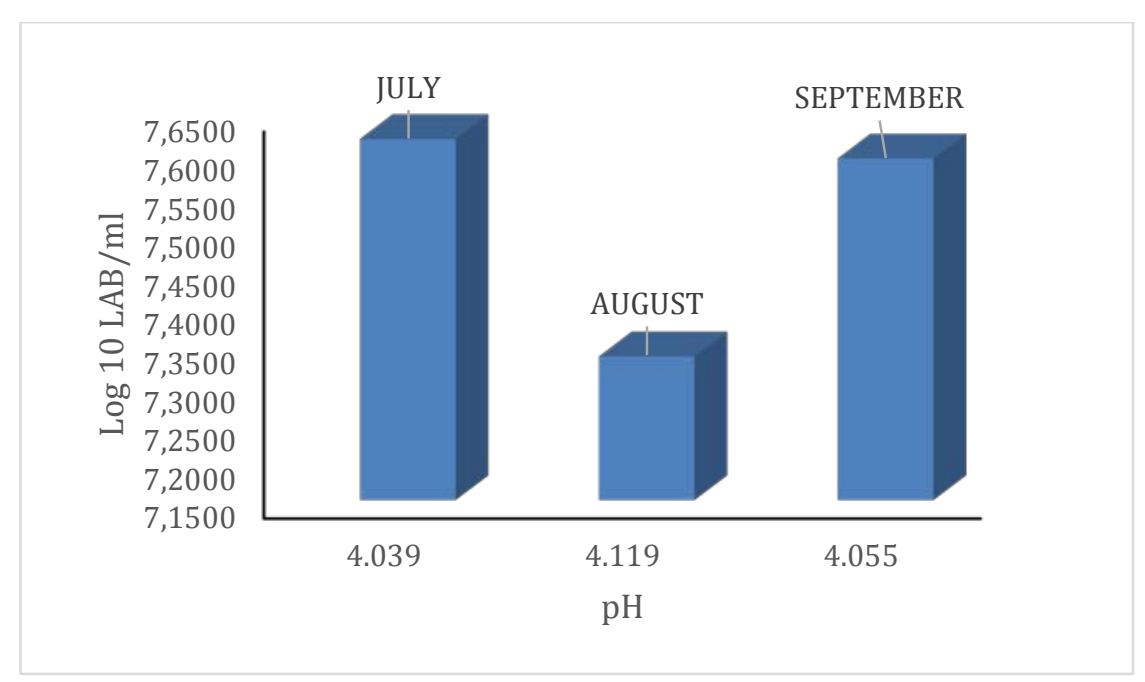

Figure 3. Correlation between $\mathrm{pH}$ and number of lactic acid bacteria 
of WSC, which results in the rapid production of lactic acid and a rapid decrease in ph and thereby leads to the suppression of nonbeneficial microbes (Ni et al., 2015). Bacterial inoculum contain large numbers of the bacteria responsible for producing lactic acid. When added to corn silage, the increased concentration of the targeted bacteria results in the levels of lactic acid increasing at a faster rate, which results in a quicker drop of $\mathrm{pH}$. The lower pH stability in the silage is used for long preservation.

In the present study, the function of lactic acid bacteria inoculant not only as a preservation, but also as probiotics. Weinberg et al. (2004) and Ellis et al. (2016) found that the viable cells of lactic acid bacteria in silage can play a role as probiotic in the rumen during fermentation process. The lower $\mathrm{pH}$ stability in the silage is used for long preservation. It can be applied for feed sustainability, in order to maintain the feed in the fluctuate weather, it was showed that silage produced in Technopark Banyumulek resulted good quality based on their stability during three months. Based on these results, it was showed that transfer technology from LIPI to the community is succesful.

\section{Conclusion}

The quality of whole corn crop silage product using $L$. plantarum $1 A-2$ from Technopark Banyumulek Lombok during 3 months showed stable fermentation process and resulted the stablity of silage quality based on microbes population of $L A B$ and $\mathrm{pH}$. Transfer technology from Research Center for Biotechnology-LIPI to the Techopark Banyumulek to the community is successful. It is very possible that transfer technology package can also be applied in other region, so the people understand the principle of silage making from the technology transferred to the community.

\section{Acknowledgements}

The research was funded by the Technopark Banyumulek Project, DIPA 2015 Research Center for Biotechnology, Indonesian Institute of Sciences.

\section{References}

Amado, I. R., C. Fucinos, P. Fajardo, N. P. Guerra, and L. Pastrana. 2012. Evaluation of two bacteriosin-producing probiotic lactic acid bacteria as inoculants for controlling Listeria monocytogenes in grass and maize silages. Anim. Feed Sci. Technol. 175:137-149.

http://dx.doi.org/10.1016/j.anifeedsci.2 012.05 .006

AOAC. 2005. Official Methods of Analysis. $18^{\text {th }}$ edn. AOAC International, Arlington, VA, USA

BMKG. 2015. Stasiun Klimatologi Klas 1 Lombok Barat. http://iklim.ntb.bmkg.go.id/index.php?p age=View $\mathrm{CH \& id=12}$. Diakses pada 24 Februari 2017.

Bolsen, I. C. K., G. Ashbell, and J. M. Wilkinnson. 1995. Silage Additives in Biotechnology in Animal Feeds and Animal Feeding. In: R. J. Wallace and A. Chesson (eds). VCH. Weinheim.

Cappuccino, J. G, and N. Sherman. 2001. Microbiology; a laboratory manual. $6^{\text {th }}$ edn. In: State University of New York (ed) Rockland Community College, NY, USA.

Coeuret, V., M. Gueguen, and J. P. Vernoux. 2004. Numbers and strains of lactobacilli in some probiotic products. Int. J. Food. Microbiol. 97: 147-156.

Ellis, J. L., A. Bannink, I. K. Hindrichsen, R. D. Kinley, and W. F. Pellikaan. 2016. The effect of lactic acid bacteria included as a probiotic or silage inoculant on in vitro rumen digestibility, total gas, and methane production. Anim. Feed Sci. Technol. 211: $61-74$.

Eweedah, N. M. 2005. Evaluation of corn stover silage and whole corn silage on growing lambs performance. J. Agric. Res. Tanta Univ. 31.

Grattepanche, F., C. Lacroix, P. Audet, and G. Lapointe. 2004. Quantification by realtime PCR of Lactococcus lactis subsp. cremoris in milk fermented by a mixed culture. J. Appl. Microbiol. Biotechnol. 66: 414-421

Harrison, J. H., R. Blauwiekel, and M. R. Stokes. 1995. Fermentation and utilization of grass silage. J. Dairy Sci. 77: 3209-3235.

Klocke, M., K. Mundt, C. Idler, J. McEniry, P. O'Kiely, and S. Barth. 2006. Monitoring Lactobacillus plantarum in grass silages with the aid of $16 \mathrm{~S}$ rDNA-based quantitative real-time PCR assays. J. Syst. Appl. Microbiol. 29: 49-58. 
Kobayashi, Y., S. Koike, H. Taguchi, H. Itabashi, H. D. K. Kam, and J. K. Ha. 2004. Recent advances in gut microbiology and their possible contribution to animal health and production - a review. Asian-Aus. J. Anim. Sci. 17: 877-884.

Lin, C., K. K. Bolsen, B. E. Brent, and D. Y. C. Dung. 1992. Epiphytic lactic acid bacteria succession during the preensiling and ensiling periods of alfalfa and maize. J. Appl. Bacteriol. 73: 375387.

Lynch, J. P., P. O'Kiely, S. M. Waters, and E. M. Doyle. 2012. Conservation characteristics of corn ears and stover ensiled with the addition of Lactobacillus plantarum MTD-1, Lactobacillus plantarum 30114, or Lactobacillus buchneri 11A44. J. Dairy Sci. 95: 2070-2080.

McDonald, P., A. R. Henderson, and S. J. E. Heron. 1991. The biochemistry of silage. In: Chalcombe publications. $2^{\text {nd }}$ (ed). Centerbury, UK.

Ni, K., Y. Wang, D. Li, Y. Cai, and H. Pang. 2015. Characterization, identification and application of lactic acid bacteria isolated from forage paddy rice silage. PLoSONE. 10: 1-14. https://doi.org/10. 1371/journal.pone.0121967

Norton, B. W. 1994. The nutritive value of tree legumes. In: Forage Tree Legumes in Tropical Agriculture. R. C. Gutteridge (eds). CABI publishing, UK. pp. 177191.

Mosoni, P., F. Chaucheyras-Durand, C. BeraMaillet, and E. Forano. 2007. Quantification by real-time PCR of cellulolytic bacteria in the rumen of sheep after supplementation of a forage diet with readily fermentable carbohydrates: effect of a yeast additive. J. Appl. Microbiol. 103: 26762685.

Ridwan, R., I. Rusmana, Y. Widyastuti, K. G. Wiryawan, B. Prasetya, M. Sakamoto, and M. Ohkuma. 2015. Fermentation characteristics and microbial diversity of tropical grass-legumes silages. Asian Australas. J. Anim. Sci. 28: 511518

Sun, Z. H., S. M. Liu, G. O. Tayo, S. X. Tang, Z. L. Tan, B. Lin, Z. X. He, X. F. Hang, Z. S. Zhou, and M. Wang. 2009. Effects of cellulase or lactic acid bacteria on silage fermentation and in vitro gas production of several morphological fractions of maize stover. Anim. Feed Sci. Technol. 152: 219-231. http://dx.doi.org/10.1016/ j.anifeedsci.2009.04.013.

Tajima, K., R. I. Aminov, T. Nagamine, $H$. Matsui, M. Nakamura, and Y. Benno. 2001. Diet-dependent shifts in the bacterial population of the rumen revealed with real-time PCR. Appl. Environ. Microbiol 67: 2766-2774.

Weinberg, Z. G., R. E. Muck, P. J. Weimer,Y. Chen, and M. Gamburg. 2004. Lactic acid bacteria used in inoculants for silage as probiotics for ruminants. Appl. Biochem. Biotechnol. 118: 1-10.

Wilkinson, J. M., K. K. Bolsen, and C. J. Lin. 2003. History of silage. In: Silage Science and Technology. D. R. Buxton (eds). Agron. Monogr. 42. ASA, CSSA, and SSSA, Madison, WI, USA, pp. 130.

Zanine, A. M., E. M. Santos, J. R. R. Dorea, P. A. S. Dantas, T. C. Silva and O. G. Pereira. 2010. Evaluation of elephant grass with adition of cassava scrapings. Revista Brasileira de Zootecnia. 39: 2611-2616. 